although, if the intermediate stages are those which are conventionally postulated, the optical activity must necessarily disappear, since the intermediate product would be symmetrical. The preservation of asymmetry can, however, be explained by means of partial valencies, through which the asymmetry of one atom is maintained until it has been stabilised again either in the same atom or in a different one.

The bearing of the theory of polarity on the reactivity of organic compounds was discussed by $\mathrm{Mr}$. E. K. Rideal, and, as illustrating this aspect of the problem, Mr. R. G. W. Norrish described some experiments which he has just carried out, according to which the union of ethylene and bromine is almost stopped by enclosing the mixed gases in a vessel lined with paraffin wax, whereas in contact with the polar surface of a glass vessel combination takes place rapidly.

In the general discussion, to which about a dozen different speakers contributed, Prof. J. F. Thorpe urged that the theory of polarity " explains everything but predicts nothing," in marked contrast to van 't Hoff's stereochemistry, which made organic chemistry into the most exact of all the sciences. This contention was strenuously denied by $\mathrm{Mr}$. Burkhardt from the Manchester laboratory and by Profs. Noyes, Lapworth, Heilbron, and Robinson, who proceeded to put on record two definite predictions in order to get over the difficulty that under normal conditions the prediction and the verification are published together, so that the reader cannot be quite certain which really came first. Dr. Flürscheim also replied in a very vigorous manner to the criticisms by Prof. Lowry of his views in reference to the influence of substitution on the strength of carboxylic acids, and urged that in several examples the formation of internal salts, which had been suggested as an alternative explanation by Prof. Lowry, cannot in fact take place. Prof. Lewis directed attention to the fact that the breaking of a double bond does not necessarily get rid of cis and trans isomerism, even if free rotation can take place; and in support of this view Mr. Bury quoted the fact that quadrivalent sulphur compounds retain their optical activity even when one of the four groups is ionised.

In the final session of the conference, Prof. Victor Henri presented a paper on "Molecular Polarity, deduced from the Study of Absorption Spectra." This proved to be a most remarkable contribution, in which the application of considerations based on the quantum theory led to the conclusion that quantified motion may occur in electrons, atoms, or molecules, giving rise to broad absorption-bands, narrow absorption-bands, and a fine structure of these bands, respectively. By making use of a source of continuous ultra-violet light, Prof. Henri has been able to study the fine structure of the absorption bands of a large number of compounds, and in some instances to measure as many as two thousand bands in the fine structure. A large number of photographs were shown to illustrate the various types of absorption spectra. Prof. Henri's paper produced a very profound impression by the masterly character both of the theory and of the experiments which he described. It may well mark a new era in the history of absorption spectra. In apologising to Prof. Henri for the fact that the late hour did not allow of an opportunity for discussion, the president added that the question of holding a general discussion on absorption spectra is already under consideration by the council of the Faraday Society, and that such a discussion would allow of a fuller consideration of the view which Prof. Henri had put forward.

\title{
International Conference of Phytopathology and Economic Entomology.
}

THE first International Conference of Phytopathology and Economic Entomology was held in Holland on June 24-July 2 by the kind invitation of the Netherlands Government in co-operation with the authorities of the various laboratories and institutes conducting work on agricultural phytopathology and entomology. The Conference was noteworthy as being the first occasion on which phytopathologists and entomologists from all countries have been invited to meet together to discuss matters of mutual interest. Prof. H. M. Quanjer of Wageningen, presided over the Conference, while Dr. L. O. Howard, Chief of the United States Bureau of Entomology, acted as president of honour. Upwards of 65 members attended-in addition to the Dutch participantsrepresenting some 26 countries. A report of the Conference, giving an account of the demonstrations, papers read, etc., will be issued by the Committee of Management (obtainable from the Secretary, Mr. T. A. C. Schoevers, of the Netherlands Phytopathological Service, Wageningen), but in the meantime the following brief account may be of interest.

Members assembled at Wageningen on June 24, when an address of welcome was delivered by Prof. Kielstra, Rector Magnificus of the University. On the following morning the Conference was formally opened by H.E. the Minister for Home Affairs and Agriculture, and during the day members attended the inauguration, by Jonkheer van Citters, of the new Laboratory for Potato Research in which Prof.
Quanjer's Department is now housed. In the laboratory and adjoining experiment station experiments of great interest, notably in connexion with the "virus" diseases of the potato, were inspected. After spending two days in conference, the members divided into two parties, one visiting Groningen and the other Boskoop, Aalsmeer and Haarlem. The first party inspected the practical application of Prof. Quanjer's experiments in the selection fields and farm of Dr. O. Botjes, who demonstrated his methods of obtaining "seed" potatoes on a large scale entirely free from virus diseases, and the second visited nurseries producing ornamental plants, shrubs and bulbs; at Lisse (near Haarlem) they visited Dr. van Slogteren's new laboratory for the study of bulb diseases, and were treated to an excellent address and to demonstrations. The two parties combined forces again at the laboratory of Prof. Westerdijk, Director of the W. C. Scholten Phytopathological Laboratory at Baarn, where the final papers were read and the discussions concluded. Subsequently H.E. the Minister for Home Affairs and Agriculture held a farewell reception at the Hague, and members were entertained to dinner at Scheveningen. Many members remained until the following week to take part in an expedition to the glass house district of the Westland.

Within a short space it is impossible to do justice to the papers read. Two subjects were, however, specially prominent-namely, (I) the research, both botanical and entomological, which centres round the

$$
\text { NO. } 2805 \text {, VOL. I } 127
$$


plant-diseases of the "virus" type, and (2) the efficiency or otherwise, of controlling the spread of insect and fungus pests from one country to another by means of a phytopathological service.

Discussions on the latter concerned chiefly plant import regulations and quarantines, the point of view of the exporting country being ably expounded by Mr. van Poeteren, who is director of the Netherlands Phytopathological Service. The controversial and difficult nature of this subject is well known, and it is satisfactory to record that the following resolution was approved :

"The representatives of all nations assembled at the International Phytopathological Conference at Wageningen, June 25-30, I923, desire to place themselves on record as in full agreement with the essentials of international trade and commerce in living plants and plant-products, namely, reasonable freedom from all insect-pests and plant-diseases of all kind of materials imported into or exported from any country."
It should also be mentioned that so greatly impressed were members with the results of the Conference in bringing about international sympathy and co-operation as to the control of diseases and pests, that it was considered imperative that similar conferences under the same title should be held in future, and a small committee, under the chairmanship of Prof. Quanjer, with Mr. Schoevers as secretary, was appointed to undertake provisionally the duties of arranging for the next conference and of dealing with the various resolutions which had been passed.

This brief summary would be incomplete if some reference were not made to the hospitality and kindness experienced. Special mention must also be made of the admirable manner in which Prof. Quanjer carried out his duties as president, and the debt members owe him for rendering the discussions clear to all by rapid translation. As secretary, $\mathrm{Mr}$. Schoevers was untiring, working literally night and day for the good of the Conference.

\section{Sir William Thiselton-Dyer.}

\section{Tribute From British Botanists.}

\section{$\mathrm{O}^{\mathrm{N}}$} July 28 Sir William Thiselton-Dyer attained his eightieth birthday and was the recipient of the subjoined letter from botanists throughout the country. Sir William's work as assistant director of the Royal Botanic Gardens, Kew, under Sir Joseph Hooker, and then as director for a memorable period of twenty years, is so well known that it is not necessary to refer to the many important things he did during his term of office. The present condition of the Gardens, and the prestige of Kew all over the world, are sufficient testimony to his ability and prescience. We beg to extend to Sir William in his retirement our congratulations and best wishes that he may long continue to enjoy his health and carry on his botanical activities.

\section{Dear Sir William,}

The occasion of your eightieth birthday affords us the opportunity of which we gladly avail ourselves, not only of offering you our congratulations upon having attained so venerable an age, but also of assuring you of our continued regard and esteem. In doing so we who sign this letter do but acknowledge our indebtedness to you for the inspiration and guidance which we, both as teachers and researchers, have derived directly or indirectly from your own early work as a professor of botany. We regard that work, and more especially the courses of practical instruction conducted by you at South Kensington in the years 1875 and 1876 , as having inaugurated the renaissance of the study of the structure and functions of plants which had been so brilliantly carried on by British botanists in earlier times. It must, we feel sure, afford you great and justifiable satisfaction to contemplate the marvellous development of such studies in this country during the years that have passed since you quickened them into new life.

The professorial career on which you had embarked so brilliantly was unfortunately, as it may have seemed at the time, brought to a close by your appointment to the assistant directorship of Kew in I875 and your subsequent appointment as director

$$
\text { NO. } 2805 \text {, vOL. I I } 2 \text { ] }
$$

ten years later. The work that you were enabled to carry out at Kew has been of such national importance, that, however much we may regret the loss of the stimulating influence you would undoubtedly have exerted as a professor, we all realise the great and lasting services you have rendered to botany, not only from the purely scientific point of view, but also in relation to the development and encouragement of botanical enterprise throughout the British Empire.

Another notable result of the interest you inspired was the successful launching of the Annals of Botany, which has come to be one of the leading botanical periodicals of the world. We do not forget that it was your enthusiasm that turned the scale when the question of " to be or not to be " hung in the balance. The Annals is a lasting monument to your courage and prescience.

It would need a lengthy document were we to attempt to set out in detail the value of your many efforts for the promotion of our science, but in conclusion we feel we must refer to the noble work you did in saving the old Chelsea Physic Garden from destruction. Thanks to you, London has now a botanic garden where students and teachers can study the structure and functions of plants and pursue those studies which you did so much to promote.

With our very kind regards and good wishes,

Believe us to be, dear Sir William,

Yours very truly,

D. H. ScotT

S. H. VINES

F. O. BOWER

F. KeEble

BALFOUR

H. T. BRown

A. B. RendLE

D. Prain

A. ShIPLEy

H. WAGER

F. F. BLACKMAN

F. DARWIN

V. H. BLACKMAN

H. H. DIXON

F. W. Olliver

A. C. SEWARD

A. G. TAnsley

J. B. FARMER

F. E. WEISS

A. W. Hill

and all the leading botanists in Great Britain and Ireland. 